\title{
PARTISIPASI MASYARAKAT DALAM PEMBANGUNAN FISIK DESA DARSONO KECAMATAN ARJASA KABUPATEN JEMBER TAHUN ANGGARAN 2014
}

\author{
SETYOWATI KARYANINGTYAS \\ Program Studi Ilmu Administrasi Publik, \\ Sekolah Tinggi Ilmu Administrasi Pembangunan Jember \\ Email: tkonge@yahoo.com
}

\begin{abstract}
ABSTRAK
Penelitian ini bertujuan untuk mendeskripsikan untuk mendeskripsikan dan menganalisis seperti apa bentuk partisipasi masyarakat dalam pembangunan

fisik di Desa Darsono Kecamatan Arjasa Kabupaten Jember Tahun 2014.

Tipe penelitian yang digunakan dalam penelitian ini adalah deskriptif kualitatif. Metode pengumpulan data yang digunakan ini adalah observasi langsung, wawancara, dan dokumentasi yang dianalisis dengan menggunakan model analisa interaktif (interactive model of system) yang dikemukan oleh Miles dan Huberman. Dan hasil dari analisis data tersebut diuji keabsahan datanya dengan cara triangulasi. Hasil penelitian ini menunjukkan bahwa bentuk partisipasi masyarakat Desa Darsono Kecamatan Arjasa Kabupaten Jember dalam pembangunan fisik tahun 2014 ada lima bentuk yakni, partisipasi buah pikiran, partisipasi tenaga dan gotong royong, partisipasi harta benda, partisipasi ketrampilan dan keahlian, dan yang terahir adalah partisipasi sosial.
\end{abstract}




\section{PENDAHULUAN}

Partisipasi menjadi sesuatu yang penting dan dibutuhkan dalam praktik administrasi publik. Pemikiran ini selain ingin menempatkan birokrasi pemerintah sebagai instrumen demokrasi, juga mencoba menggunakan birokrasi pemerintah sebagai alat untuk menampung aspirasi masyarakat. Implikasi dari pemikiran itu adalah bahwa sistem administrasi publik memiliki dimensi ruang dan wilayah yang penyelenggaraannya juga dipengaruhi oleh keterlibatan masyarakat dan lingkungannya. Kesemuanya itu menuntut reorientasi peran birokrasi pemerintahan yang condong pada upaya untuk meningkatkan desentralisasi dan makin mendekatkan pelayanan kepada masyarakat. Hal yang kemudian melahirkan paradigma baru gerakan administrasi publik yang disebut sebagai gerakan administrasi publik baru. Korten (dalam Muluk, 2007:5) menyatakan bahwa :

"Partisipasi memiliki nilai yang sangat penting dalam berbagai proses pembangunan sehingga pembangunan dapat dijalankan untuk meningkatkan martabat manusia sebagaimana tertuang dalam gagasan

\section{dasarnya people centered} development."

Partisipasi memiliki arti penting dalam proses pembangunan sebab bermanfaat dalam meningkatkan kualitas keputusan yang dibuat karena didasarkan pada kepentingan dan pengetahuan riil yang ada di dalam masyarakat. Partisipasi juga bermanfaat dalam membangun komitmen masyarakat untuk membantu penerapan suatu keputusan yang telah dibuat. Komitmen ini merupakan modal utama bagi keberhasilan sebuah implementasi kebijakan. Mengingat fungsi dan manfaat yang dapat dipetik darinya, kini partisipasi tidak lagi dapat dipandang sebagai kesempatan yang diberikan oleh pemerintah tetapi justru sebagai hak masyarakat. Partisipasi dapat dianggap sebagai layanan dasar dan bagian integral dari local governance (Muluk, 2007:6). Dalam perkembanganya, pengejawantahan pola relasi antara negara dan masyarakat serta pendekatan pembangunan dapat diwujudkan dalam beberapa strategi pembangunan salah satunya dalam bentuk program pemberdayaan masyarakat. Hal tersebut bertujuan guna tercapainya tujuan pembangunan nasional serta masifnya partisipasi masyarakat dalam pembangunan nasional. 
Seperti halnya program-program pembangunan yang selama ini menjadi tujuan bersama. Programprogram pembangunan tersebut merupakan salah satu upaya untuk mendorong partisipasi masyarakat dalam pembangunan, serta untuk mengetahui tingkat keberhasilan pembangunan desa dan kelurahan dengan melihat pada orisinalitas gagasan, kreativitas, aktivitas, upaya penguatan kelembagaan dan peningkatan motivasi serta semangat swadaya gotong royong masyarakat.

Pembangunan daerah yang efektif dan efisien memerlukan perencanaan yang teliti akan penggunaan sumber daya yang tersedia, baik sumber daya publik atau swasta. Dalam Undang-Undang Nomor 25 Tahun 2004 tentang Sistem Perencanaan Pembangunan Nasional, dalam pasal 3 Ayat 1, 2, dan 3 menyatakan bahwa perencanaan pembangunan nasional mencakup penyelenggaraan perencanaan makro semua fungsi pemerintahan yang meliputi semua bidang kehidupan secara terpadu dalam wilayah Negara Republik Indonesia. Perencanaan pembangunan nasional tersebut menghasilkan:

a. Rencana pembangunan jangka panjang (RPJP)

b. Rencana pembangunan jangka menengah (RPJM) c. Rencana

pembangunan

tahunan/ Rencana Kerja

Pemerintah (RKP)

Dalam Undang-Undang

Nomer 25 tahun 2004 tersebut juga mengatur tahapan-tahapan pembangunan yang sekaligus dijadikan dasar berjalannya pembangunan di kota Pasuruan, antara lai sebagai berikut.
a. Penyusunan rencana
b. Penetapan rencana
c. Pengendalian perencanaan rencana
d. Evaluasi pelaksanaan rencana Pembangunan fisik di Desa Darsono yang menjadi pokok bahasan peneliti, bertujuan untuk mendorong partisipasi masyarakat. Pembangunan tahunan dalam bentuk fisik ini merupakan hasil output dari Musrenbang. Pembangunan ini dilaksanakan melalui empat tahapan, antara lain penyusunan rencana, penetapan rencana, pelaksanaan rencana dan evaluasi. Tahapan tersebut merupakan tahapan yang sudah diatur dalam Undang-Undang Nomor 25 tahun 2004. Desa Darsono Kecamatan Arjasa Kabupaten Jember, merupakan desa yang menurut pemerintah setempat memiliki partisipasi mayarakat yang cukup bagus. Hal ini dibuktikan dengan banyaknya penghargaan yang diterima Desa seperti juara lomba Desa mandiri, baik dalam kegiatan pembangunan, maupun perawatan lingkungan yang dilaksanakan 
melalui kegiatan Bulan Bhakti gotong royong dengan partisipasi masyarakat yang cukup tinggi diantara desa-desa lain yang ada di Kabupaten Jember.

Hal inilah yang mendorong keingintahuan peneliti untuk meninjau ulang bagaimana partisipasi masyarakat yang terjadi di Desa Darsono. Untuk mengetahui partisipasi yang terjadi maka harus diketahui bagaimana proses-proses pembangunan berlangsung. Berdasarkan penjelasan di atas maka peneliti tertarik untuk melakukan penelitian dengan judul "Partisipasi Masyarakat Dalam Pembangunan Fisik Desa Darsono Kecamatan Arjasa Kabupaten Jember Tahun Anggaran 2014".

\section{TINJAUAN PUSTAKA}

Pembangunan merupakan
rangkaian usaha mewujudkan
pertumbuhan dan perubahan secara terencana dan sadar yang ditempuh oleh suatu negara bangsa menuju modernitas dalam rangka pembinaan bangsa (Siagian, 2003:4). Menurut Todaro (dalam Hidayat, et al, 2007:1) pembangunan merupakan proses multidimensional yang menyangkut perubahan-perubahan penting dalam suatu struktur, sistem sosial ekonomi, sikap masyarakat dan lembaga-lembaga nasional dan akselerasi pertumbuhan ekonomi, pengangguran kesenjangan

(inequality) dan pemberantasan kemiskinan absolut. Dalam pengertian ini pembangunan meliputi tiga aspek yang sama pentingnya, yaitu mempertinggi kehidupan berbangsa, menciptakan keadaan yang dapat membantu pertumbuhan rasa harga diri, serta mengembangkan kebebasan untuk memilih dengan jalan memperluas kesempatan untuk memilih.

Untuk

tercapainya

keberhasilan pembangunan, maka segala program perencanaan, pelaksanaan serta evaluasi pembangunan harus melibatkan masyarakat. Sebab masyarakat yang mengetahui permasalahan dan kebutuhan dalam rangka membangun wilayahnya, masyarakat nantinya yang akan memanfaatkan dan menilai tentang berhasil atau tidaknya pembangunan di wilayah mereka. Dari sinilah dapat disimpulkan bahwa Partisipasi memiliki arti penting dalam proses pembangunan sebab bermanfaat dalam meningkatkan kualitas keputusan yang dibuat karena didasarkan pada kepentingan dan pengetahuan riil yang ada di dalam masyarakat. Partisipasi juga bermanfaat dalam membangun komitmen masyarakat untuk membantu penerapan suatu keputusan yang telah dibuat.

Kajian partisipasi dalam administrasi publik merupakan 
perhatian penting sebagai nilai dasar demokrasi. Dalam administrasi publik gagasan partisipasi mencakup dua ranah, yakni manajemen partisipatif dan partisipasi masyarakat dalam administrasi publik. Osborn dan Gaebler (dalam Muluk, 2007:29) mengungkapkan dua prinsip yang menyentuh dua ranah tersebut ketika memasukkannya dalam prinsipprinsip reinventing government :

a.

rinsip "community owned government: empowering rather than serving" yang menunjukkan betapa pentingnya partisipasi masyarakat dalam administrasi publik.

b.

$\begin{array}{lr}\text { rinsip } & \text { "decentralized } \\ \text { govermen: from hierarchi } \\ \text { to participation and } \\ \text { teamwork" } & \text { yang } \\ \text { menunjukkan } & \text { betapa } \\ \text { pentingnya } & \text { manajemen } \\ \text { partisipatif } & \text { yang } \\ \text { memungkinkan } & \text { partisipasi } \\ \text { karyawan } & \text { dalam } \\ \text { penyelenggaraan } & \\ \text { administrasi publik. }\end{array}$

Oleh $\begin{gathered}\text { karena } \\ \text { partisipatif }\end{gathered}$ sangat
pembangunan
penting peranannya dalam mencapai
keberhasil pembangunan. Menurut
definisi konseptual dari Keith Davis
(dalam Huraerah 2011:95) "participation is defined as mental and emotional involvement of person in group situation that encourage them to contribute to group goals and share responsibility for them ". Dari definisi tersebut maka makna partisipasi mengandung tiga pokok gagasan, yaitu keterlibatan emosional, dorongan untuk memberi sumbangan, dan penerimaan tangung jawab. Ada berbagai bentuk partisipasi menurut para ahli, salah satunya yang dikemukakarP oleh Hamijoyo dan Iskandar, 2011:116 yang akan digunakan dalam penelitian ini. Bentuk partisipasi yang dikemukakan oleh Hamijoyo dan Iskandar memperinci jenis-jenis partisipasi sebagai lima jenis berikut ini.

a. Partisipasi buah pikifan, yang diberikan partisipan dalam anjang sono, pertemuan atau rapat.

b. Partisipasi tenaga, yang diberikan partisipan dalam berbagai kegiatan untuk perbaikan atau pembangunan desa, pertolongan bagi orang lain dan sebagainya.

c. Partisipasi harta benda, yang diberikan orang dalam berbagai kegiatan untuk perbaikan atau pembangunan desa, pertolongan bagi orang lain dan sebagainya.

d. Partisipasi keterampilan dan kemahiran, yang diberikan orang untuk mendorong 
aneka ragam bentuk usaha dan industri.

e. Partisipasi sosial, yang diberikan orang sebagai tanda keguyuban, misalnya turut arisan, koperasi, layad (dalam peristiwa kematian), kondangan (dalam peristiwa pernikahan), nyambungan, mulang sambung.

Proses pembangunan tahunan di Desa Darsono tahun 2014 diawali dengan proses perencanaan pembangunan. Proses perencanaan pembangunan ini dijalankan dengan berpedoman kepada hasil Musrenbang tahun sebelumnya. Dengan pedoman yang sudah ada, proses perencanaan pembangunan dijalankan melalui musyawarah dengan perwakilan masyarakat Desa Darsono. Dalam kegiatan ini, semua yang hadir mewakili masyarakat di masing-masing Rukun tetangga dan Rukun Warga, mereka dipersilahkan untuk menyampaikan aspirasinya dalam mengusulkan pembangunan yang akan dilaksanakan dengan mengacu pada rekomendasi hasil Musrenbang tahun sebelumnya. Tahapan kedua adalah tahap pelaksanaan, dalam tahapan ini masyarakat akan menjalankan apa yang sudah menjadi kesepakatan dalam proses perencanaan pembangunan. Dengan difasilitasi oleh Tim Pelaksana Pembangunan, diharapkan proses pelaksanaan pembangunan ini bisa berjalan dengan lancar sesuai kesepakatan sudah dibicarakan pada waktu forum perencanaan di desa. Secara tidak langsung memang mekanisme dalam tahapan pelaksanaan pembangunan sudah semestinya direncanakan pada waktu itu, sehingga dapat menuntun masyarakat untuk terus bisa mengawal pembangunan secara intensif. Masyarakat memang diposisikan sebagai subyek pembangunan, agar nantinya dapat tercipta suasana demokratis dan transparan.

Lain halnya dengan tahapantahapan pembangunan di atas. Tahapan evaluasi dalam pembangunan memiliki prosedur sendiri untuk pelaporan hasil kegiatan khusunya terkait masalah dana. Tim pelaksana pembangunan ini nantinya harus melaporkan dalam bentuk SPJ (Surat Pertanggung Jawaban) yang akan diberikan kepada pemerintah daerah, malalui SKPD (Satuan Kerja Pemerintah Daerah) terkait. Hal ini merupakan bentuk pertanggung jawaban Tim Pelaksanaan Pembangunan yang sudah mengawal pelaksanaan pembangunan di desa sehingga nantinya bisa menjadi bahan evaluasi untuk pembangunan kedepan, baik untuk pemerintah setempat pada umumnya, serta untuk tim pelaksana itu sendiri khusunya. Masyarakat dalam tahapan ini memang tidak terlihat memiliki peran yang cukup 
penting, tetapi masyarakat sama sekali tidak dibatasi haknya untuk mengetahui maslah-masalah terkait pembangunan itu. Dalam artian masyarakat bisa melihat hasil pelaporan ataupun pemanfaatan dana yang sudah direalisasikan dalam bentuk pembangunan yang sudah ada tersebut.

\section{METODOLOGI PENELITIAN}

Fokus penelitian ini adalah partisipasi masyarakat dalam tahap perencanaan, penetapan rencana, dan tahap pelaksanaan pembangunan di Desa Darsono, Kecamatan Arjasa, Kabupaten Jember pada tahun 2014. Tipe penelitian yang digunakan adalah deskriptif kualitatif. Tempat penelitian di desa Darsono, kecamatan Arjasa, kabupaten Jember yang dilaksanakan pada bulan Oktober 2014 sampai Desember 2014. Penentuan informan dilakukan dengan cara purposive sampling atau penentuan informan dengan cara yang disengaja karena orang tersebut dianggap tahu tentang masalah yang akan dijawab dalam penelitian. Teknik pengumpulan data dilakukan melalui observasi langsung, wawancara, dan dokumentasi. Sedangkan model analisis data yang digunakan adalah analisa data interaktif (interactive model of system) yang dikemukan oleh Miles dan Huberman (1992:20). Teknik pemeriksaan keabsahan data dilakukan dengan cara triangulasi. Moleong mengatakan (2010:178), "trianggulasi adalah teknik pemeriksaan keabsahan data yang memanfaatkan sesuatu yang lain di luar data itu untuk keperluan pengecekan atau sebagai pembanding terhadap data itu".

\section{HASIL DAN PEMBAHASAN}

Desa Darsono merupakan
bagian dari wilayah kecamatan Arjasa kabupaten Jember, dengan jarak tempuh $2 \mathrm{~km}$ ke kecamatan terdekat dengan waktu berkisar 0,15 jam. Sedangkan jarak menuju ibu kota kabupaten Jember sejauh $10 \mathrm{Km}$ dan lama tempuh yang diperlukan untuk menuju ke ibu kota kabupaten berkisar 0,5 jam. Desa Darsono berada pada ketinggian $141 \mathrm{~m}$ di atas permukaan air laut, perbukitan/pegunungan dengan luas 555 Ha dan memilki curah hujan $2700 \mathrm{~mm} / \mathrm{th}$. Desa Darsono berbatasan langsung dengan 4 desa lain, yaitu sebagai berikut.

- Sebelah Utara :

Desa/kelurahan Kamal

- Sebelah Timur :

Desa/Kelurahan Arjasa

- Sebelah Selatan : Desa / Kelurahan Kemuninglor

- Sebelah Barat : Desa / Kelurahan Kemuninglor 
Dari hasil penelitian di lapangan, maka peneliti dapat menganalisis sebagai berikut:

1. Ruang lingkup dalam penelitian ini adalah partisipasi masyarakat dalam proses pembangunan tahunan, sebab peneliti hanya fokus pada tahap perencanaan, tahap penetapan rencana serta pelaksanaan kegiatan pembangunan tahunan yang diadakan di Desa Darsono tahun 2014 saja.

2. Kriteria bentuk partisipasi yang dikemukakan oleh Hamijoyo dan Iskandar terdiri dari 5 kriteria yaitu, partisipasi buah pikiran, partisipasi tenaga, partisipasi harta benda, partisipasi keterampilan dan kemahiran, partisipasi sosial. Dari hasil wawancara peneliti menggunakan 5 kriteria yang disebutkan Hamijoyo dan Iskandar. 5 kriteria yang dipakai peneliti dalam menganalisa hasil temuan dilapangan yaitu partisipasi buah pikiran, partisipasi tenaga atau gotong royong, dan partisipasi sosial, partisipasi harta dan benda, serta partisipasi keterampilan dan kemahiran. Partisipasi tersebut memang terjadi dalam prosesproses pembangunan sekalipun beberapa memang terlihat minim.

3. Penelitian ini termasuk dalam partisipasi prosesional.
Dikatakan partisipasi prosesional karena seluruh bentuk partisipasi yang dipakai peneliti untuk melihat serta menganalisi adanya partisipasi yang terjadi dalam pembangunan fisik Desa Darsono itu ditemukan seluruhnya dilapangan, mulai dari partisipasi buah pikiran, kemudian partisipasi harta benda, partisipasi tenaga, partisipasi keterampilan dan kemahiran, serta partisipasi sosial, kesemuanya itu terjadi dalam pembangunan fisik di Desa Darsono.

Analisis hasil penelitian tentang partisipasi masyarakat dalam kegiatan pembangunan tahunan Desa Darsono tahun anggaran 2014 dapat dilihat dalam keterangan di bawah ini:

\section{a. Perencanaan}

Berikut ini merupakan pembahasan serta analisis hasil penelitian dalam tahapan perencanaan terkait partisipasi masyarakat dalam pembangunan fisik Desa Darsono tahun anggaran 2014, antara lain sebagai berikut:

1) Partisipasi Buah Pikiran

Dalam kriteria ini berkaitan dengan adanya keterlibatan masyarakat dalam menyampaikan ide dan usulan yang berkaitan dengan pembangunan sebagaimana dalam perencanaan pembangunan itu memang sangat diperlukan untuk mewujudkan demokrasi. Dalam 
pelaksanaan pembangunan yang diawali dengan proses perencanaan, bisa dilihat dari kegiatan perencanaan pembangunan yang dilaksanakan di Desa Darsono, tim pelaksana pembangunan melakukan perencanaan bersama masyarakat yang menjadi perwakilan, seperti yang terjadi pada saat MUSRENBANG. Masyarakat merasa sudah dilibatkan secara langsung, seperti yang disampaikan bapak Rifa'I, bapak Kholili, dan bapak Supardi saat perencanaan pembangunan mereka sudah menyampaikan aspirasi dan usulan mereka dengan berpedoman pada rekomendasi Musrenbang sehingga terwujud pembangunan yang ada pada waktu itu. Namun, pada saat perencanaan yang lebih rijik lagi mengenai masalah teknis pembangunan, mereka sudah mempercayakan kepada perwakilan masyarakat yang ada dalam tim pelaksana pembangunan. Jadi masyarakat lebih telihat aktif dalam partisipasi buah pikiran itu dalam awal perencanaan pembangunan.

2) Partisipasi Sosial

Sedangkan tingkat kehadiran masyarakat dalam agenda pembangunan juga dapat dikategorikan dalam partisipasi sosial. Tingkat kehadiran yang dimaksud adalah intensitas keikutsertaan warga dengan mereka datang mengahadiri rapat, sekalipun hanya sekedar datang ini sudah bisa dikategorikan sebagai partisipasi sosial. Dalam tahap perencanaan ini memang yang hadir adalah bagian perwakilan dari warga masyarakat Desa Darsono, jadi tidak semua warga bisa menghadiri forum rapat ini. Tetapi bisa dikatakan intensitas kehadiran warga masyarakat yang menjadi perwakilan dari masingmasing RT dan RW ini termasuk banyak, dan ini bisa dibuktikan dengan daftar absensi yang sudah ada. Begitu pula yang disampaikan Bpk.Sukirman dan Pak Susiono, selaku penasehat dan ketua tim pelaksana pembangunan seperti dalam wawancara dibawah ini.

\section{b. Penetapan Rencana}

Berikut ini merupakan pembahasan serta analisis hasil penelitian dalam tahapan penetapan rencana terkait partisipasi masyarakat dalam pembangunan fisik Desa Darsono tahun anggaran 2014, antara lain sebagai berikut:

1) Partisipasi Buah Pikiran

Dalam kriteria ini berkaitan dengan adanya keterlibatan masyarakat dalam menyampaikan ide dan usulan yang berkaitan dengan pembangunan sebagaimana dalam perencanaan pembangunan itu memang sangat diperlukan untuk mewujudkan demokrasi. Dalam pelaksanaan pembangunan yang diawali dengan proses perencanaan, bisa dilihat dari kegiatan perencanaan pembangunan yang 
dilaksanakan di Desa Darsono, tim pelaksana pembangunan melakukan perencanaan bersama masyarakat yang menjadi perwakilan, seperti yang terjadi pada saat MUSRENBANG. Masyarakat merasa sudah dilibatkan secara langsung, seperti yang disampaikan bapak Rifa'I, bapak Kholili, dan bapak Supardi saat perencanaan pembangunan mereka sudah menyampaikan aspirasi dan usulan mereka dengan berpedoman pada rekomendasi Musrenbang sehingga terwujud pembangunan yang ada pada waktu itu. Namun, pada saat perencanaan yang lebih rijik lagi mengenai masalah teknis pembangunan, mereka sudah mempercayakan kepada perwakilan masyarakat yang ada dalam tim pelaksana pembangunan. Jadi masyarakat lebih telihat aktif dalam partisipasi buah pikiran itu dalam awal perencanaan pembangunan.

2) Partisipasi Sosial

Sedangkan tingkat kehadiran masyarakat dalam agenda pembangunan juga dapat dikategorikan dalam partisipasi sosial. Tingkat kehadiran yang dimaksud adalah intensitas keikutsertaan warga dengan mereka datang mengahadiri rapat, sekalipun hanya sekedar datang ini sudah bisa dikategorikan sebagai partisipasi sosial. Dalam tahap perencanaan ini memang yang hadir adalah bagian perwakilan dari warga masyarakat
Sekargadung, jadi tidak semua warga bisa menghadiri forum rapat ini. Tetapi bisa dikatakan intensitas kehadiran warga masyarakat yang menjadi perwakilan dari masingmasing RT dan RW ini termasuk banyak, dan ini bisa dibuktikan dengan daftar absensi yang sudah ada. Begitu pula yang disampaikan Bpk.Sukirman dan Pak Susiono, selaku penasehat dan ketua tim pelaksana pembangunan seperti dalam wawancara dibawah ini.

\section{c. Pelaksanaan}

Berikut ini merupakan pembahasan serta analisis hasil penelitian dalam tahapan pelaksanaan terkait partisipasi masyarakat dalam pembangunan fisik Desa Darsono tahun anggaran 2014, dalam tahapan ini analisa hasil penelitian lebih di spesifikkan kepada masing-masing objek pembangunan antara lain sebagai berikut.

\section{1) Partisipasi Buah Pikiran}

Dari hasil wawancara di atas, dapat disimpulkan bahwa dalam pelaksanaan pembangunan di Desa Darsono memiliki partisipasi buah pikiran yang minim, tetapi masih ada indikasi bahwa partisipasi ini terjadi. Tim pelaksana pembangunan dalam menjalankan tugasnya juga selalu menerima masukan dari masyarakat untuk dijadikan pertimbangan seperti yang disampaikan pak Susiono dalam wawancara di atas. Selain itu 
tim pelaksana pembangunan juga selalu merapatkan (mengkoordinasikan) segala sesuatu yang berkaitan dengan pembangunan fisik dengan ketua RT dan RW setempat sehingga pembangunan berjalan lancar. Pak Bawon juga menyampaikan bahwa beliau sering ditemani $\mathrm{n}$ mendapatkan masukan terkait pembangunan.

\section{2) Partisipasi Tenaga}

Partisipasi tenaga atau gotong royong juga Nampak dalam kegiatan pembangunan plengsengan sungai ini. Adanya keterlibatan warga yang mau membantu ikut mengerjakan pembangunan ini merupakan bentuk nyata dari adanya partisipasi tenaga, yang diwujudkan dengan kerja bhakti pada waktu awal pembangunan pelengsengan sungai dan jembatan ini. Pak Susiono, Pak Zainul, Pak Hari dalam wawancara juga menyampaikan bahwa yang ikut berpartisipasi pada waktu kerja bhakti saat pembukaan awal pembangunan plengsengan sungai ini cukup banyak, tetapi dalam perjalanannya, pada waktu pengerjaan plengsengan dan jembatan tidak banyak yang ikut seperti pada saat kerja bhakti, secara rasional memang tidak mungkin dalam pengerjaan plengsengan sungai dan jembatan ini seluruh warga ikut turun semuanya dalam bentuk tenaga atau gotong royong, dikarenakan masyarakat desa ini memiliki tanggung jawab sendirisendiri, dan memang sudah ada tenaga ahli dan kuli yang mengerjakan hal itu sehingga keikutsertaan beberapa warga dalam membantu tenaga itu sudah cukup. Pak Bawon pun menyampaikan bahwa para pemuda dan beberapa warga sering sekali membantu dia dalam pembangunan tersebut, seperti ikut mengangkat batu, mengangkat timba semen sampai ikut menurunkan semen-semen pada saat pengiriman.

3) Partisipasi Harta Benda

Bisa dikatakan warga masyarakat Desa Darsono dalam partisipasi harta benda ini juga ada, bisa dilihat dari kepedulian warga untuk membantu memberikan makanan dan minuman sekedarnya, seperti yang disampaikan dalam hasil wawancara di atas oleh pak zainul dan pak susiono serta beberapa warga masyarakat.

4) Partisipasi Keterampilan dan Kemahiran

Salah satu Tukang yang mengerjakan pembangunan plengsengan sungai di RT.01/RW.I Desa Darsono merupakan warga asli RT.01/RW.I Desa Darsono sendiri, yaitu pak Bawon. itu juga merupakan hasil kesepakatan warga pada waktu rapat perencanaan dan penetapan rencana seperti yang tertera dalam surat tugas dari Tim Pelaksana pembangunan. Masyarakat juga mengakui bahwa hal itu akan 
memberikan efek yang positif untuk warga sekitar khususnya yang berprofesi sebagai tukang seperti yang disampaikan oleh Pak Rifa'I dan Pak kholili dalam wawancara di atas, karena selain memberikan manfaat bagi tukang yang mengerjakan juga akan lebih memberikan stimulus agar supaya masyarakat yang lain juga terdorong untuk membantu.

\section{5) Partisipasi Sosial}

Dalam tahapan pelaksanaan warga yang hadir lumayan banyak, selalu ada beberapa dari warga masyarakat RT.01/RW.I Desa Darsono yang ikut memantau, sekalipun tidak semua warga bisa datang untuk melihat atau memantau karena mereka memiliki kesibukan sendiri setiap harinya. Tetapi bisa dikatakan intensitas kehadiran warga masyarakat dari RT ini termasuk banyak bahkan dari RT dan RW lain yang masih masuk dalam wilayah territorial Desa Darsono, khususnya pada waktu kerja bhakti dalam pengerjaan pelengsengan sungai dan pembuatan jembatan itu yang paling banyak dari pada pembangunan yang lain seperti yang disampaikan Pak Susiono dan Pak Hari, sama dengan yang disampaikan Pak Zainul (ketua RT.01/RW.I) sebisanya beliau meluangkan waktunya untuk sekedar memantau dan datang ke lokasi pembangunan, Pak Bawon pun menyampaikan hal yang senada, beliau merasa sangat dibantu sekali dengan kehadiran warga yang setiap hari ikut membantunya sekalipun tidak semuanya.

\section{KESIMPULAN}

Dari hasil penelitian di lapangan, peneliti dapat menyimpulkan mengenai evaluasi kegiatan pemberian bantuan fasilitas dalam rangka Partisipasi Masyarakat Dalam Pembangunan Fisik Rencana Kerja Pembangunan Desa Darsono Kecamatan Arjasa Kabupaten Jember Tahun 2014. Kesimpulan yang di dapat sebagai berikut:

a. Partisipasi Buah Pikiran

1) Perencanaan Pembangunan.

Partisipasi buah pikiran lebih terlihat dalam tahap ini, seperti yang disampaikan oleh beberapa anggota tim pelaksana dengan melihat antusiasme perwakilan warga dalam mengemukakan pendapatnya sehingga menjadi bahan pertimbangan yang sangat berarti dalam pembangunan di Desa Darsono.

2) Penetapan Rencana

Dalam tahap ini, partisipasi buah pikiran sudah mulai terlihat minim, dikarenakan usulan yang sebelumnya sudah disampaikan dalam tahap sebelumnya, yakni tahapan perencanaan itu sudah tinggal penetapan saja dan di wujudkan dalam bentuk proposal pembangunan.

3) Pelaksanaan Pembangunan 
Pada waktu pelaksanaan ada sedikit partisipasi buah pikiran yang diberikan beberapa warga sekitar untuk membantu tim pelaksana dalam memberikan pengarahan kepada tukang yang mengerjakan pos kamling. Tim pelaksana pembangunan dalam menjalankan tugasnya juga selalu menerima masukan dari masyarakat untuk dijadikan pertimbangan. Selain itu tim pelaksana pembangunan juga selalu merapatkan (mengkoordinasikan) segala sesuatu yang berkaitan dengan pembangunan fisik dengan ketua RT dan RW setempat sehingga pembangunan berjalan lancar.

\section{b. Partisipasi Tenaga dan Gotong} Royong

Partisipasi tenaga, yang diberikan partisipan dalam

berbagai kegiatan untuk perbaikan atau pembangunan desa, pertolongan bagi orang lain dan sebagainya. Dalam kegiatan pembangunan Desa Darsono tahun anggaran 2014 partisipasi tersebut terjadi dengan cukup baik dibanding partisipasi masyarakat dalam tahapan pelaksanaan pembangunan. Hanya saja kurang maksimal. Dalam artian kurang maksimal dikarenakan masyarakat memilki kesibukan sehari-hari yang tidak bisa ditinggalkan. Tetapi dalam kegiatan pembangunan pelengsengan sungai, masyarakat terlihat antusias dalam gotong royon membantu membersihkan daerah sungai serta membantu tukang dalam pengerjaannya.

\section{c. Partisipasi Harta dan Benda}

Lain halnya dengan dua bentuk partisipasi di atas, partisipasi harta dan benda dalam pelaksanaan pembangunan ini terjadi secara spontan. Tanpa ada permintaan ataupun himbauan dari pihak pemerintah dan tim pelaksana, masyarakat sekitar yang daerahnya kedapatan mendapat jatah pembangunan, rata-rata masyarakatnya membantu memberikan support berupa makanan dan minuman. Hal ini sangat membantu menunjukkan kepedulian warga sekitar dalam menyukseskan pembangunan. Secara tidak langsung masyarakat sudah termasuk berpartisiasi dalam hal partisipasi harta dan benda.

\section{d. Partisipasi Keterampilan dan kemahiran}

Berdasarkan dari kesepakatan masyarakat, masalah tenaga ahli terkait pembangunan yang akan dilaksanakan di Desa Darsono, tenaga tukang ataupun kuli 
seandainya bisa lebih baik diberikan kepada warga yang memiliki keahlian dibidang itu.

Beberapa Tukang dan keseluruhan kuli yang mengerjakan pembangunan di Desa Darsono merupakan warga Desa Darsono sendiri, itu juga merupakan hasil kesepakatan warga pada waktu rapat. Masyarakat juga mengakui bahwa hal itu akan memberikan efek yang positif untuk warga sekitar, karena selain memberikan manfaat bagi tukang yang mengerjakan juga akan lebih memberikan stimulus agar supaya masyarakat yang lain juga terdorong untuk membantu.

\section{e. Partisipasi Sosial}

1) Perencanaan Pembangunan.

Partisipasi social dalam tahap perencanaan pembangunan juga dapat dikategorikan cukup baik. Dari jumlah peserta rapat yang seharusnya hadir, hampir keseluruhan peserta selalu hadir dalam tiap-tiap agenda rapat yang berhubungan dengan perencanaan pembangunan di Desa Darsono, dan ini bisa dibuktikan dengan daftar absensi yang sudah ada.

2) Penetapan Rencana

Tidak berbeda jauh dengan tahap perencanaan, partisipasi social dalam tahapan penetapan rencana juga dapat dikategorikan cukup baik. Begitupun jumlah peserta rapat yang seharusnya hadir, hampir keseluruhan peserta hadir dalam rapat penetapan rencana pembangunan yang dilaksanakan di Desa Darsono, dan ini bisa dibuktikan dengan daftar absensi yang sudah ada.

3) Pelaksanaan Pembangunan.

Dalam tahapan pelaksanaan warga yang hadir memang tidak selalu banyak di setiap lokasi pembangunan, tetapi bisa dikatakan warga Desa Darsono yang datang untuk melihat proses pembangunan itu pasti ada, tidak semua warga bisa datang untuk membantu karena mereka memiliki kesibukan sendiri setiap harinya. Kehadiran warga masyarakat yang paling banyak adalah pada saat kerja bhakti dalam pengerjaan pelengsengan sungai dan pembuatan jembatan.

Setelah melakukan penelitian tentang Partisipasi Masyarakat Dalam Pembangunan Fisik di Desa Darsono Kecamatan Arjasa Kabupaten Jember, peneliti mempunyai beberapa saran berikut ini.

a. Untuk pihak Desa Darsono serta Tim Pelaksana Pembangunan agar lebih diperhatikan mengenai catatan, arsip atau agenda serta 
dokumentasi kegiatan apa saja yang menyangkut pembangunan guna mempermudah pencarian data dan informasi untuk ke depannya.

b. Pembangunan di Desa Darsono sebenarnya sangat efektif dalam memberikan stimulus bagi warga sekitar dalam meningkatkan partisipasinya terkait masalah pembangunan apabila memiliki kematangan dalam perencanaan hingga akhir pelaksanaan kegiatan, serta pembagian tugas dan sosialisasi yang jelas akan memberikan hasil yang lebih optimal.

c. Pemerintah akan lebih menyentuh dan mengetahui permasalahan yang dihadapi masyarakat dan dapat memberikan solusi yang tepat guna memecahkan permasalahan tanpa menimbulkan masalah kepada pihak lainnya dengan cara-cara melibatkan masyarakat dalam kegiatan-kegiatan seperti pembangunan ini, paling tidak ruang koordinasi antara pemerintah dan warga sekitar akan memberikan pola relasi yang saling menguntungkan minimal membangun citra pemerintah agar supaya bisa lebih dipercaya lagi oleh masyarakat.

d. Keterbukaan pemerintah mengenai kegiatan pembangunan ini kepada masyarakat luas baik pelaksana maupun pihak lain yang sangat mendukung keberlanjutan pembangunan kedepannya.

e. Dana atau anggaran yang terbatas dan terlalu mengandalkan bantuan dari pemerintah juga mempengaruhi pelaksanaan pembangunan dan hasil pembangunan yang kurang maksimal, oleh karena itu perlu disusun strategi yang matang untuk mengajak warga sekitar bisa peduli juga terhadap pendanaan/anggaran guna mengoptimalkan pencapaian pembangunan tanpa harus mengandalkan alokasi dana dari pemerintah untuk kemandirian masyarakat bukan berarti juga menolak bantuan pemerintah.

\section{DAFTAR PUSTAKA}

Adi, Rianto. 2004. Metodologi Penelitian Sosial dan Hukum. Jakarta: Granit

Bakri, Masykuri dkk. 2003. Metodologi Penelitian Kualitatif (Tinjauan Teoritis dan Praktis. Malang: Lembaga Penelitian Universitas Islam Malang Kerjasama dengan VISIPRESS.

Basrowi dan Suwandi. 2008. Memahami Penelitian Kualitatif. Jakarta: Rineka Cipta 
Hidayat, Wisnu, dkk. Tanpa tahun.

Kebijakan dan manajemen:

Pembangunan partisipatif.

Yogjakarta: YPAP

Huraerah,

Abu.

2011.

Pengorganisasian

\&

Pengembangan Masayarakat

Model \& Strategi

Pembangunan Berbasis

Kerakyatan.

Bandung:

Humaniora

Kartasamita, Ginanjar. 1997.

Administrasi Pembangunan

dan Praktiknya di Indonesia.

Jakarta: LP3ES

Moleong, Lexy. 2010. Metodologi

Penelitian

Kualitatif.

Bandung: PT. Remaja

RosdaKarya.

Muluk, Khairul, MR, Dr, M,si. 2007.

Menggugat Partisipasi Public

Dalam

Pemerintahan

Daerah. Malang: Bayumedia Publishining.

Ndraha, Taliziduhu. 1983.Partisipasi

Dalam Pembangunan. Jakarta:

LP3ES.

Ndraha,

Taliziduhu.

1990.Pembangunan

Masyarakat Mempersiapkan

Masyarakat Tinggal Landas.

Jakarta: Rineka Cipta.

Nawawi, Hadari. 1998. Metode

Penelitian Bidang Sosial.

Yogyakarta: Gajah Mada

University Press.

Pasaribu, I.L dan Simandjuntak, B.

1986.

Sosiologi
Pembangunan. Bandung:

Tarsito.

Sastrosaputro, Santoso. 1988.

Partisipasi, Komunikasi,

Persuasi dan Disiplin dalam

Pembangunan Nasional.

Bandung: Penerbit Alumni.

Siagian, Sondang P. 2003.

Administrasi Pembangunan,

Konsep, Dimensi dan

Strategi. Jakarta : Bumi

Aksara

Sugiyono. 2008. Metode Penelitian

Kuantitatif Kuaalitatif dan $R$ \&

$D$. Bandung: PT. Alfabeta.

Surjono, Agus dan Nugroho, Trilaksono. 2008. Paradigma

Model Pendekatan

Pembangunan dan

Pemberdayaan Masyarakat di era Otonomi Daerah. Malang: Lembaga Penerbit \& Dokumentasi FIA-UNIBRAW.

Suyanto, Bagong. 2005, Dakwah

Pemberdayaan

Masyarakat:Paradigma Aksi

Metodologis, Yogjakarta:

Pustaka pesantren.

Tangkilisan, Hessel Nogi S. 2005.

Manajemen Publik. Jakarta: PT

Gramedia Widiasarana

Usman, Hasaini dan Akbar, Purnomo

Setiadi. 2003. Metodologi

Penelitian Sosial. Jakarta:

Bumi

Aksar 